\title{
Peptide 946-Tetanus Peptide Conjugate Melanoma Vaccine
}

National Cancer Institute

\section{Source}

National Cancer Institute. Peptide 946-Tetanus Peptide Conjugate Melanoma Vaccine.

NCI Thesaurus. Code C2467.

A melanoma peptide vaccine complexed with tetanus toxoid with potential antineoplastic activity. Peptide 946 contains a melanoma-specific epitope recog nized by melanomaspecific cytotoxic T lymphocytes (CTL). In addition to the peptide 946 sequence, this vaccine contains tetanus toxin, a protein known to stimulate the induction of CD4+ $T$ lymphocytes; it thereby enhances antigen processing and presentation. Vaccination with the peptide 946-tetanus conjug ate melanoma vaccine may produce antibodies as well as elicit a cytotoxic T lymphocyte (CTL) response in tumor cells expressing the 946 epitope, thereby decreasing tumor cell growth. 